\title{
GRAVITY MODEL: A BIBLIOMETRIC ANALYSIS AND DETAILED OVERVIEW
}

\author{
Ismail Metin* \\ Manisa Celal Bayar University \\ Gencay Tepe \\ Manisa Celal Bayar University
}

\begin{abstract}
Originating from Newton's gravitational theory which was posed in 1687 ; the concept of gravity equation was primarily used by Tinbergen in the field of international trade analysis in 1962. After Tinbergen, Pöyhönen, Linnemann, Anderson, Santos and Tenreyro, Bergstrand and Egger, Deardorff and also Wooldridge developed the theory of gravity. And gravity model has become progressively well-liked in the academic publications. The aim of this study is to determine the literature belonging to the years between 1980 which is the starting point for "gravity" related studies' being published on Web of Science (WoS) and Scopus and 2020 to execute a bibliometric review of this literature. Thereby, it targets to supply a perspective concerning the nature of the studies executed on the subject of gravity model, so as to point out the lack of the bibliometric analysis-using studies on the field of international trade. In this study, we collected the data between 1980-2020 from Scopus and Web of Science database and analysed using the Gephi, Vosviewer and $\mathrm{R}$ Studio programmes in order to be used in our bibliometric analysis. The results showed that U.S.A., Germany and China are the countries which have the highest number of publications in this field, and the journals with the highest number of publications are "World Economy", "Journal of International Economics" and "Review of International Economics". The fact that three programmes have been simultaneously used in the study is demonstrative of the originality of the paper.
\end{abstract}

Keywords: International Trade, Gravity Model, Bibliometric Analysis, Scopus, Web of Science.

Received: 27 February 2020

Accepted: 30 December 2020

https://doi.org/10.33736/ijbs.3183.2021

\footnotetext{
- Corresponding author: As. Prof. Dr. PhD., Department of Economics and Finance, Faculty of Business, Manisa Celal Bayar University, Manisa, Turkey; Tel: 0090-5334291305; Email: dr.i.metin@gmail.com
} 


\section{INTRODUCTION}

Originating from Newton's gravitational theory which was posed in 1687; the concept of gravity model was primarily used in a study of Tinbergen in the field of international trade analysis (Tinbergen, 1962). This traditional gravity model basically expressed that the act of trading taking place among two states is shaped in a positive way by each of these countries' GDP values whereas distance negatively effects the amount of trade (Chaney, 2013; Linnemann, 1966). The gravity model provides not only the measurement of the economic elements but also of the uneconomic elements' impacts on the international trade such as distance, language, population, etc.

The gravity model claims the presence of a direct link existing among the economic mass of the commerce activities and the bilateral trade whereas the link between the bilateral trade and trade costs of the countries is an indirect one (Tinbergen, 1962). This model has generally been used on various data sets and amplified by bilateral trade variants ranging from common language to contiguity and from population size to per capita income (Linnemann, 1966; Bergstrand, 1989). It has also been used with the purpose of scrutinising the impact of different variants such as the regional trading blocs home-market effects and WTO membership on trade flows (Frankel, 1997; Rose, 2004). The model can be established like the following:

$$
\mathrm{C}_{\mathrm{TA}}=\beta_{0} \mathrm{G}^{\beta 1}{ }_{\mathrm{T}} \mathrm{G}^{\beta 2}{ }_{\mathrm{A}} \mathrm{U}^{\beta 3}{ }_{\mathrm{TA}}
$$

Where $\mathrm{C}_{\mathrm{TA}}$ is the movement of exports to country A from country $T, \mathrm{G}_{\mathrm{T}}$ and $\mathrm{G}_{\mathrm{A}}$ are country $\mathrm{T}$ 's and country A's GDP and $\mathrm{U}_{\mathrm{TA}}$ is the scope between the countries' capitals.

It is possible to encounter some articles in the publications about the international trade flows (Bergstrand, 1985; Bikker, 1987; Kepaptsoglou, Karliftis, \& Tsamboulas, 2010; Gencer, 2012; Chaney, 2013) while there are some others about economic integrations (Karemera, Smith, Ojah, \& Cole, 1999; Cheng \& Wall, 2005; Karagöz \& Karagöz, 2009; Ekanayake, Mukherjee, \& Veeramacheneni, 2010; Irshad, Xin, Shahriar, \& Arshad, 2017), foreign direct investments (Gopinath \& Echeverria, 2004; Subasat \& Bellos, 2013; Pericoli, Pierucci, \& Ventura, 2014; Mele \& Quarto, 2017) and international migration theory (Karemera et al, 1999; Lewer \& Berg, 2008; Kim \& Cohen, 2010; Beine, Bertoli \& Moraga, 2016; Solmaz \& Koç, 2019). Especially, there are plenty of research about the trade flows concerning the gravity model. However, there is no effort to execute a bibliometric analysis on the gravity model in the literature. Thus, with the help of this study a survey of researches realised in the last forty-one years will be maintained in the literature.

In spite of the fact that there is an apparent problem in the literature concerning the presence of systematic chronological studies demonstrating the development of the gravity model in history, there is no study executed with a statistical method of analysis aiming to provide a supplementary inside. Therefore, what this study targets, is to determine and to compute the literature belonging to the years 1980-2020 concerning the subject of gravity and to execute a bibliometric review of this literature. This bibliometric analysis, which is frequently preferred by professional researchers, serves to assess the results, significance and the impact of not only the authors but also institutes and journals concerning a specific field of research.

In parallel with the aim of the bibliometric analysis in general; this study, specifically targets a bibliometric review of a specific subject; "the gravity model" with the purpose of foregrounding the survey of the scientific development of the gravity model from 1980 till 2020 by verifying the 
references in the literature; hence demonstrating the fluctuations in the number of studies in different years. The contribution of this paper to the related literature is its use of three different programmes simultaneously so as to execute a bibliometric analysis which has not been encountered on this subject's analyses. The article targets to supply a perspective concerning the nature of the studies executed on the subject of gravity model, so as to point out the lack of the bibliometric analysis-using studies on the field of international trade.

\section{RESEARCH METHODOLOGY AND DATA COLLECTION}

In this part of the study, academic studies on the "Gravity Model" which were realised between 1980-2020 have been analysed on the Scopus and Web of Science (WoS) database. Required information have been acquired from this database and a bibliometric analysis has been executed. In spite of the fact that the gravity model was primarily used in international trade in 1960s, since the studies concerning the gravity model were first published in Scopus in 1980 and in WoS in 1984, the studies beginning from 1980 lasting till July 2020 have been included in this study.

\section{BIBLIOMETRIC ANALYSIS}

Bibliometric analysis can be defined as an area of research used in the analysis of contemporary tendencies encountered while scrutinizing the literature concerning a specific field of interest. What the bibliometric analysis particularly aims, is to demonstrate a comprehensive outline which sketches the structure of the research field (Muhuri, Shukla, \& Abraham, 2019). Therefore, it is on the way of becoming a fundamental methodology for analysing research, and its roots dates back to the developments in the fields of librarianship and informational technologies. In the literature there are lots of articles about bibliometric analysis in different research areas (Olczyk, 2016; Caya \& Neto, 2018; Palmer, Sese \& Montano, 2005; Nobre \& Tavares, 2017; Yeung, Goto \& Leung, 2017; Merigó \& Núñez, 2016).

In this part of the study, findings related to bibliometric analysis have been presented. The study has been divided into subtitles such as the development of the research, the most productive countries and collaboration analysis, the distribution of the most cited publications per year, bibliometric match and word analysis.

\subsection{The Development of the Research}

The research has been limited with the studies on the Scopus and Web of Science database which were published between 1980-2020 and are concerned with the international trade. The keywords of the study have been determined by using the codes "gravity-model and international-trade" and "gravity-model and foreign-trade" on both Scopus and WoS databases. The designated keywords have been scanned so as to scrutinize the titles, summaries and keywords of the publications present in the Scopus and WoS data bases and in a way to cover all the studies published till the date of July 01, 2020. Additionally, an intertextual smart scan has been executed with the help of algorithms supported by databases so as not to miss any publications related to the subject. As a result of the related procedures, the study has been conducted with a number of 738 publications 
on Scopus data base and 817 on WoS. The formulization of the analysis methods used in the bibliometric analysis have been coded with the help of R Studio 1.2 programme as R-based. The data processed via the programme has also been processed by the Gephi 0.8.2 programme and the outputs have been acquired.

Figure 1: Publications on the Gravity Model in Foreign Trade per Year (Scopus and WoS)

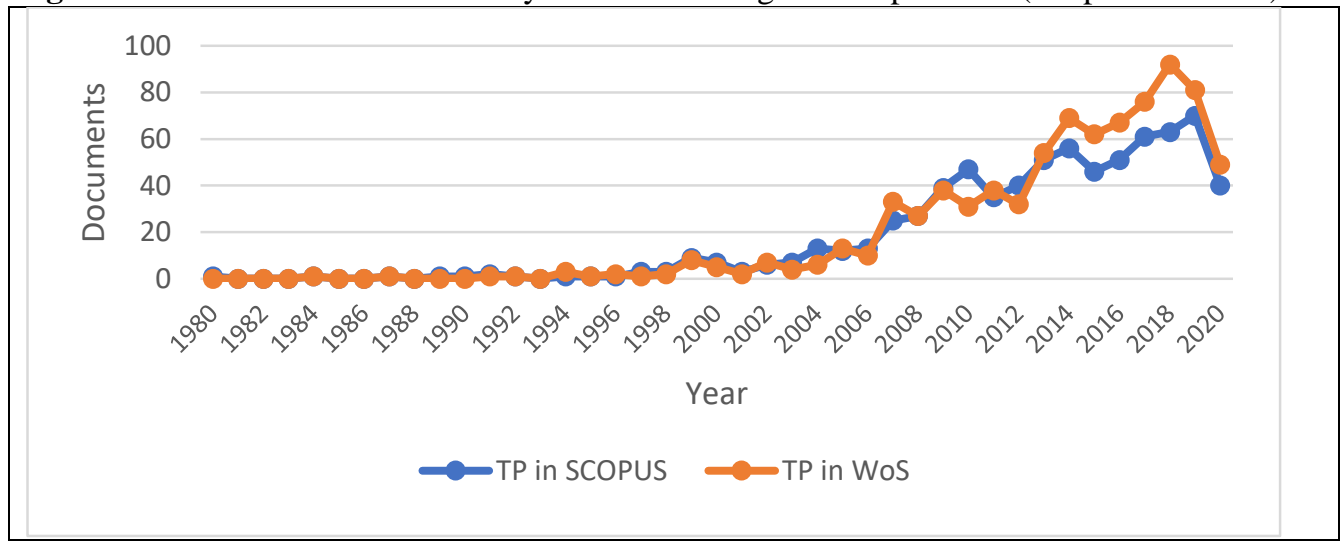

The distribution of the publications related to the Gravity Model in international trade between 1980-2020 per year is demonstrated in Figure 1. When the data was examined, it has been observed that the first study which handles the subject of "gravity model" in the field of international trade was published in 1980 on Scopus data base, whereas on WoS the first publication date is 1984. According to this distribution, for Scopus, there are 40 publications in the first half of 2020, 70 in 2019, 63 in 2018 and only 1 in 1980 whereas for WoS this number is 49 in the first half of 2020, 81 in 2019, 92 in 2018 and 1 in 1984. Although there are periodical decrease and increases, it can clearly be stated that there is an apparent increase in the 41 years period of time.

\subsection{The Most Productive Authors}

The performance indicators that are present in the research are the Total Publication (TP)- which demonstrates the total number of publication related to the subject, Total Citation (TC) which demonstrates the total number of citation that the related publications have together, Citation Per Publication (CPP) which demonstrates the number of citation per publication and which is acquired by dividing TC to TP. Lastly, the H-index is a performance indicator which is used to evaluate the scientific publication of the researcher.

The most productive authors are ranked according to their TP numbers. The authors which have the same number of publications are again ranked among themselves according to their number of citations. The most productive authors ranked according to this method are given on Table 1. For the Scopus database, 'Inma Martinez-Zarzoso' is the first author who has the highest contribution to the literature with his 14 publications and 222 citations. He is followed by 'Ehsan Rasoulinezhad' with 26 TC. The third, fourth, fifth, sixth, seventh, eighth and ninth authors who have the same 
number of publications, but different number of citations are 'Andrew K. Rose' (TC=822), 'Volker Nitsch' (TC=412), 'John Sullivan Wilson' (TC=162), 'Tristan Kohl' (TC=95), 'Peter Egger' (TC=91), 'Stefano Schiavo' $(\mathrm{TC}=44)$ and 'Vicente Pinilla' $(\mathrm{TC}=41)$ all having 5 publications each. They are followed by 'Gabriel Felbermayr' $(\mathrm{TC}=169)$. Authors with the highest number of CPP are 'Andrew K. Rose' $(\mathrm{CPP}=164.4)$ and 'Volker Nitsch' $(\mathrm{CPP}=82.4)$. For Web of Science data base, 'Inma Martinez-Zarzoso' is the most contributive author to the literature with 227 citations and 20 publications. He is followed by 'Laura Marquez-Ramos' with 107 TC and 'Ehsan Rasoulinezhad' with 37 TC. The fourth, fifth, sixth and seventh authors have 6 publications, and these authors are 'Maria Santana-Gallego' (TC=320), 'Robert Aurelian Sova' (TC=80), 'Lenka Fojtikova' $(\mathrm{TC}=18)$ and 'Simakova Jana' $(\mathrm{TC}=13)$. Along with these writers, the eighth, ninth and tenth most contributive authors to the literature are 'Andrew K. Rose' (TC=993), 'Peter Egger' ( $\mathrm{TC}=234)$ and 'Tristan Kohl' $(\mathrm{TC}=96)$. Similar to the Scopus database, it has been observed that the author with the highest CPP value is 'Andrew K. Rose' $(\mathrm{CPP}=198.6)$.

Table 1: The Most Productive 10 Authors on The Scopus and WoS Database

\begin{tabular}{cccccc}
\hline \hline & & Scopus & & & \\
\hline $\mathrm{R}$ & Authors & TP & TC & CPP & h-index \\
\hline 1 & Inma Martinez-Zarzoso & 14 & 222 & 15.8 & 7 \\
2 & Ehsan Rasoulinezhad & 6 & 26 & 4.3 & 4 \\
3 & Andrew K. Rose & 5 & 822 & 164.4 & 5 \\
4 & Volker Nitsch & 5 & 412 & 82.4 & 3 \\
5 & John Sullivan Wilson & 5 & 162 & 32.4 & 5 \\
6 & Tristan Kohl & 5 & 95 & 19 & 5 \\
7 & Peter Egger & 5 & 91 & 18.2 & 3 \\
8 & Stefano Schiavo & 5 & 44 & 8.8 & 3 \\
9 & Vicente Pinilla & 5 & 41 & 8.2 & 4 \\
10 & Gabriel Felbermayr & 4 & 169 & 42.2 & 3 \\
\hline \multicolumn{7}{c}{} & Authors & TP & TC & CPP & h-index \\
\hline 1 & Wna Martinez-Zarzoso & 20 & 227 & 11.3 & 9 \\
2 & Laura Marquez-Ramos & 8 & 107 & 13.4 & 6 \\
3 & Ehsan Rasoulinezhad & 8 & 37 & 4.6 & 4 \\
4 & Maria Santana-Gallego & 6 & 320 & 53.3 & 5 \\
5 & Robert Aurelian Sova & 6 & 80 & 13.3 & 4 \\
6 & Lenka Fojtikova & 6 & 18 & 3 & 2 \\
7 & Simakova Jana & 6 & 13 & 2.2 & 3 \\
8 & Andrew K. Rose & 5 & 993 & 198.6 & 5 \\
9 & Peter Egger & 5 & 234 & 46.8 & 4 \\
10 & Tristan Kohl & 5 & 96 & 19.2 & 5 \\
\hline \hline
\end{tabular}

\subsection{The Most Productive Journals}

In this part of the study, journals and sources which embody the highest number of publications concerning the subject are given. TP, TC and H-indexes of the journals and sources are demonstrated in Table 2 and Table 3. They are ranked according to their publication numbers. For Scopus, "World Economy" is in the first place with 42 publications and 803 citations on the related subject. It is followed by the "Review of International Economics" ( $\mathrm{TP}=15, \mathrm{TC}=351)$, "Journal Of International Economics" $(\mathrm{TP}=14, \mathrm{TC}=916)$ which is the third in the publication 
number with the highest number of citations. It is followed by "Journal Of International Trade And Economic Development" ( $\mathrm{TP}=13, \mathrm{TC}=166)$, "Applied Economic Letters" $(\mathrm{TP}=13, \mathrm{TC}=106)$, "European Economic Review" (TP=10, TC=441), "Applied Economics" (TP=10, TC=167), "Economics Letters" $(\mathrm{TP}=10, \mathrm{TC}=146)$, "Review Of World Economics" $(\mathrm{TP}=9, \mathrm{TC}=301)$ and "International Trade Journal" ( $\mathrm{TP}=9, \mathrm{TC}=62)$.

When the WoS data are scrutinised, it is discovered that the first rank in the most productive journals list "World Economy" $(\mathrm{TP}=30, \mathrm{TC}=465)$ is the same. It is possible to say that the "Journal of International Economics" ( $\mathrm{TP}=18, \mathrm{TC}=1498)$ has a very high citation impact when compared to the other journals in parallel with the results of the Scopus database.

These journals are followed by the "Review of World Economics" $(\mathrm{TP}=18, \mathrm{TC}=359)$, "Applied Economics" $(\mathrm{TP}=17, \mathrm{TC}=312)$, "Journal Of International Trade And Economic Development" $(\mathrm{TP}=17, \mathrm{TC}=95)$ and "Review Of International Economics" $(\mathrm{TP}=13, \mathrm{TC}=162)$. The last four ranks of the 10 most productive journals list on the Web of Science data base is shared by "Economics Letters" $(\mathrm{TP}=10, \mathrm{TC}=128)$, "Agricultural Economics" $(\mathrm{TP}=10, \mathrm{TC}=62)$, "Applied Economics Letters" $(\mathrm{TP}=10, \mathrm{TC}=39)$, "Emerging Markets Finance and Trade" $(\mathrm{TP}=10, \mathrm{TC}=24)$ with equal publication numbers. When the journals, congresses and sources giving place to gravity model publications are scrutinized, the fact that high quality and peer-reviewed journals publish these demonstrate the high amount of the subject's contribution to the literature.

Table 2: Most Productive 10 Journals That Have Publications on the Subject of Gravity Model (Scopus)

\begin{tabular}{lrcc}
\hline \hline $\mathrm{R}$ Scopus & TP & TC & h-index \\
Journal & 42 & 803 & 15 \\
\hline 1 World Economy & 15 & 351 & 9 \\
2 Review Of International Economics & 14 & 916 & 9 \\
3 Journal Of International Economics & 13 & 166 & 6 \\
4 Journal Of International Trade And Economic Development & 13 & 106 & 4 \\
5 Applied Economics Letters & 10 & 441 & 6 \\
6 European Economic Review & 10 & 167 & 7 \\
7 Applied Economics & 10 & 146 & 4 \\
8 Economics Letters & 9 & 301 & 8 \\
9 Review Of World Economics & 9 & 62 & 4 \\
10 International Trade Journal & & & \\
\hline \hline
\end{tabular}


Table 3: Most Productive 10 Journals That Have Publications on the Subject of Gravity Model (WoS)

\begin{tabular}{lrrc}
\hline \hline $\mathrm{R} \quad$ WoS & TP & TC & h-index \\
Journal & 30 & 465 & 11 \\
\hline 1 World Economy & 18 & 1498 & 14 \\
2 Journal of International Economics & 18 & 359 & 9 \\
3 Review of World Economics & 17 & 312 & 9 \\
4 Applied Economics & 17 & 95 & 6 \\
5 Journal Of International Trade And Economic Development & 13 & 162 & 7 \\
6 Review Of International Economics & 10 & 128 & 4 \\
7 Economics Letters & 10 & 62 & 4 \\
8 Agricultural Economics & 10 & 39 & 3 \\
9 Applied Economics Letters & 10 & 24 & 3 \\
10 Emerging Markets Finance and Trade & & & \\
\hline \hline
\end{tabular}

\subsection{Productivity and Academic Collaboration Analysis of the Countries}

In this part of the study, outputs acquired by data and total citation numbers of the countries have been graded according to their TP by stating their CPP and h-indexes. This gradation is demonstrated in Table 4. In the Scopus database, United States of America ranks first with a number of 170 publications and 4433 citations to these publications.

Table 4: Most Productive Countries

\begin{tabular}{lcccclcccc}
\hline \hline $\begin{array}{l}\text { R Scopus } \\
\text { Countries }\end{array}$ & TP & TC & CPP & h-index & $\begin{array}{l}\text { R WoS } \\
\text { Countries }\end{array}$ & TP & TC & CPP & h-index \\
\hline 1 USA & 170 & 4433 & 26.1 & 35 & 1 USA & 185 & 5236 & 28.3 & 33 \\
2 Germany & 85 & 1781 & 20.9 & 20 & 2 China & 96 & 327 & 3.4 & 9 \\
3 China & 82 & 565 & 6.9 & 12 & 3 Germany & 90 & 1133 & 12.6 & 18 \\
4 Spain & 47 & 714 & 15.2 & 17 & 4 Spain & 64 & 925 & 14.4 & 16 \\
5 Italy & 36 & 805 & 22.4 & 14 & 5 UK & 58 & 2625 & 45.3 & 19 \\
6 France & 35 & 421 & 12.1 & 9 & 6 France & 41 & 907 & 22.1 & 11 \\
7 UK & 34 & 947 & 27.8 & 16 & 7 Italy & 41 & 458 & 11.1 & 10 \\
8 Australia & 29 & 238 & 8.2 & 9 & 8 Canada & 40 & 584 & 14.6 & 11 \\
9 Netherlands & 28 & 460 & 16.4 & 11 & 9 Czechia & 31 & 77 & 2.5 & 5 \\
10 Canada & 27 & 413 & 15.3 & 9 & 10 Netherlands & 28 & 548 & 19.6 & 13 \\
\hline \hline
\end{tabular}

It is observed that in the Scopus database, minimum 35 publications in USA has minimum 35 citations (h-index=35). Germany, China and Spain follow USA with publication numbers of 85,82 and 47. The highest CPP belongs to United Kingdom $(27,8)$, USA $(26,1)$, and Italy $(22,4)$. Lastly the lowest CPP belongs to China $(6,9)$ and Australia $(8,2)$ although they are in the top 10 most productive countries ranking. When WoS database is examined, USA has the position of the most productive country with 185 publications and 5236 citations. When it is compared with the Scopus database, it is observed that China, Germany and Spain follow USA with publication numbers of 96, 90 and 64 respectively. Countries with the highest CPP value are United Kingdom (45,3), USA $(28,3)$ and France $(22,1)$. The lowest CPP values, on the other hand, belong to Czechia $(2,5)$ and China $(3,4)$. When both Scopus and WOS databases are scrutinised, it can be concluded that the 
post productive country is USA, whereas upon scrutinising the CPP values the most influential country in terms of citation per publication number is observed to be the United Kingdom. In spite of the fact that China ranks second and third in the gradation of publication number, its citation number is low when compared to other countries. In quantity, USA's gravity model studies internationally published in the Scopus and Web of Science database are in a higher level when compared to the other countries.

Figure 2: Demonstration of the Collaboration Analysis of Countries via the Mapping Method (Scopus)

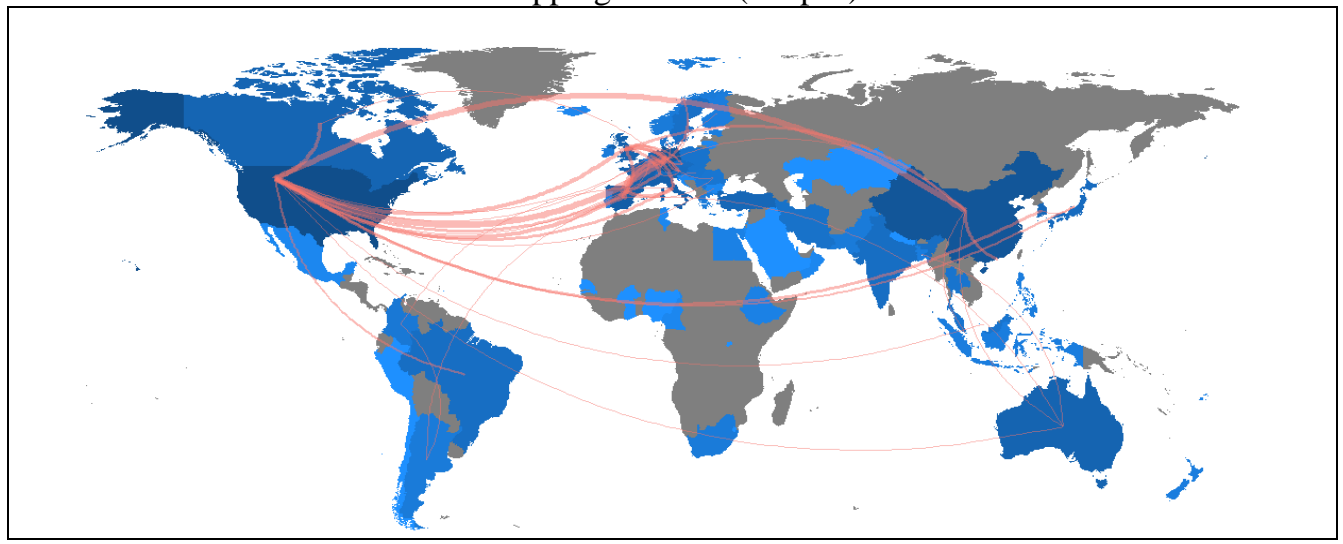

The collaboration analysis of the countries is demonstrated in Figure 2 and Figure 3. The higher number of publications of the countries are demonstrated with darker blues. The authors defined with red line demonstrated that they have collaborated with other countries' authors. The mapping of the results of the collaboration analysis on the Scopus database is given place on Figure 2. Accordingly, it is observed that the highest number of collaborations is 15 which is realised between Germany and Spain. Along with these, there are 12 collaborations between USA and Germany, 11 between China and USA and 11 between Germany and United Kingdom in their publications. According to the analysis which was realised upon examining the citation numbers, it is possible to state that Germany makes use of the United Kingdom and USA based publications as its main source, and that similarly, China makes use of USA sources more frequently as the main source when compared to the other countries. 
Figure 3: Demonstration of the Collaboration Analysis of Countries via the Mapping Method (Web of Science)

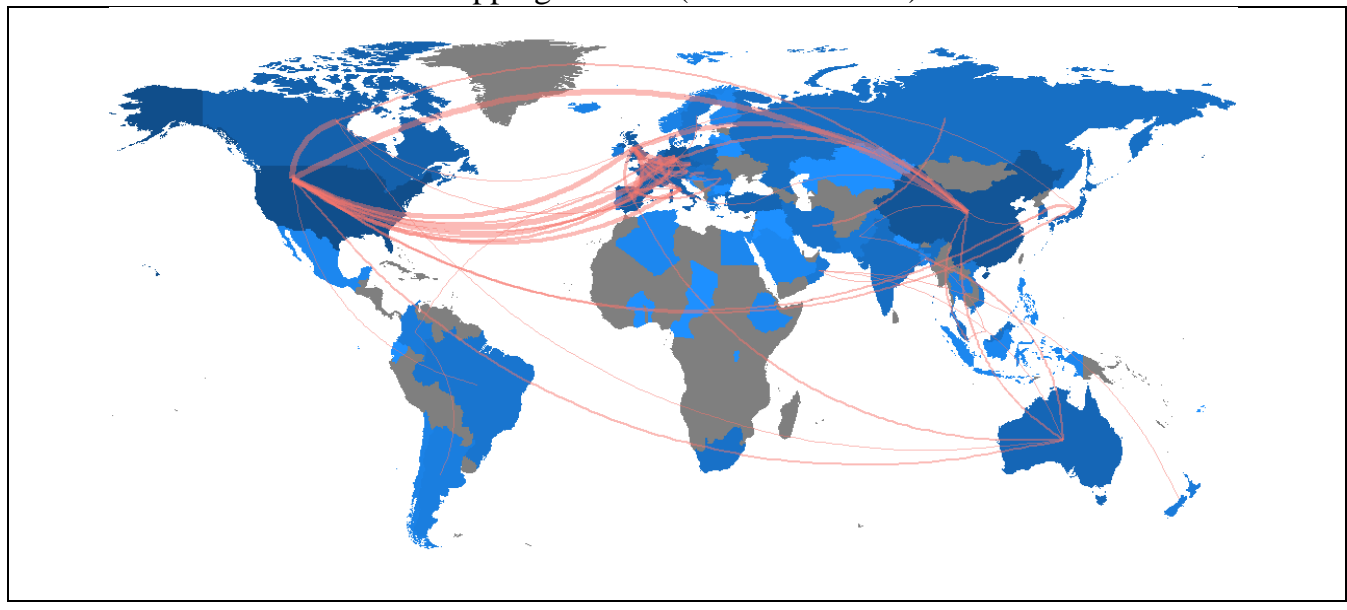

Concerning the WoS, the results of the collaboration analysis are demonstrated on Figure 3. Additionally, it is possible to say that the highest number of collaborations is 18 which took place between both Germany-Spain and United Kingdom-Germany. Canada's collaboration number in gravity model studies is 13 , which was realized with USA. When the citations are examined, it can be observed that the source publications China uses belongs to the authors who make publications in USA.

\subsection{Most Influential Publications}

In this part of the study, top 10 articles most frequently cited in Scopus and WoS have been examined. In Table 5 and Table 6 you can find the names of the studies and the distribution of their citations per years (in the sources part all the publications are given). In the Scopus database, the publication with the highest number of citations is Rose (2004) with 596 citations. The second highest citation belongs to Kaluza, Kölzsch, Gastner, and Blasius (2010) publication with a number of 473 citations. The other publications exceeding 200 citations are (Anderson \& Marcouiller, 2002) TC $=373$, (Subramanian $\&$ Wei, 2007) TC $=283$, (Burger, Van Oort, $\&$ Linders, 2009) $\mathrm{TC}=225$, (Morrow, Siverson \& Tabares, 1998) TC $=210$. The seventh, eighth, ninth and tenth most influential publications are (Dür, Baccini \& Elsig, 2014) TC=186, (Nitsch, 2000) TC=185, (De Benedictis \& Tajoli, 2011) TC=167 and (Costantini \& Mazzanti, 2012) TC=165 with citation numbers below 200 . 
Table 5: Distribution of the Most Cited Publications' Number of Citations Per Year (Scopus)

\begin{tabular}{|c|c|c|c|c|c|c|c|c|}
\hline Publication & P.Year & $<2016$ & 2016 & 2017 & 2018 & 2019 & 2020 & Total \\
\hline $\begin{array}{l}\text { Do we really know that the WTO } \\
\text { increases trade? }\end{array}$ & 2004 & 458 & 34 & 36 & 21 & 32 & 15 & 596 \\
\hline $\begin{array}{l}\text { The complex network of global } \\
\text { cargo ship movements }\end{array}$ & 2010 & 208 & 46 & 51 & 57 & 73 & 38 & 473 \\
\hline $\begin{array}{l}\text { Insecurity and the pattern of trade: } \\
\text { An empirical investigation }\end{array}$ & 2002 & 249 & 23 & 22 & 37 & 19 & 23 & 373 \\
\hline $\begin{array}{l}\text { The WTO promotes trade, strongly } \\
\text { but unevenly }\end{array}$ & 2007 & 182 & 24 & 25 & 21 & 19 & 12 & 283 \\
\hline $\begin{array}{l}\text { On the specification of the gravity } \\
\text { model of trade: Zeros, excess zeros } \\
\text { and zero-inflated estimation }\end{array}$ & 2009 & 92 & 33 & 18 & 34 & 33 & 15 & 225 \\
\hline $\begin{array}{l}\text { The political determinants of } \\
\text { international trade: The major } \\
\text { powers, 1907-90 }\end{array}$ & 1998 & 154 & 12 & 10 & 21 & 12 & 1 & 210 \\
\hline $\begin{array}{l}\text { The design of international trade } \\
\text { agreements: Introducing a new } \\
\text { dataset }\end{array}$ & 2014 & 20 & 22 & 29 & 37 & 50 & 28 & 186 \\
\hline $\begin{array}{l}\text { National borders and international } \\
\text { trade: Evidence from the European } \\
\text { Union }\end{array}$ & 2000 & 134 & 17 & 11 & 13 & 7 & 3 & 185 \\
\hline The World Trade Network & 2011 & 60 & 21 & 16 & 35 & 20 & 15 & 167 \\
\hline $\begin{array}{l}\text { On the green and innovative side of } \\
\text { trade competitiveness? the impact of } \\
\text { environmental policies and } \\
\text { innovation on EU exports }\end{array}$ & 2012 & 57 & 18 & 19 & 19 & 28 & 24 & 165 \\
\hline
\end{tabular}

The publication with the highest number of citations on the WoS database belongs to Portes and Rey (2005) with 563 citations. The second highest number of citations is Rose (2004) with 493 citations. The other influential publications with a number of citations above 200 are (Anderson $\&$ Marcouiller, 2002) TC=334, (Rose, 2000) TC $=324$, (Anderson, 2011) $\mathrm{TC}=287$, (Carrere, 2006) $\mathrm{TC}=246$, (Cheng \& Wall, 2005) $\mathrm{TC}=212$ and (Burger et al., 2009) $\mathrm{TC}=206$. The ninth and tenth ranked publications, on the other hand, have a number of citations below 200 and these are (Egger, 2002) $\mathrm{TC}=178$ and (Fourie \& Santana-Gallego, 2011) $\mathrm{TC}=173$. 
Table 6. Distribution of the Most Cited Publications' Number of Citations Per Year (WoS)

\begin{tabular}{|c|c|c|c|c|c|c|c|c|}
\hline Publication & P.Year & $<<2016$ & 2016 & 2017 & 2018 & 2019 & 2020 & Total \\
\hline $\begin{array}{l}\text { The determinants of cross-border } \\
\text { equity flows }\end{array}$ & 2005 & 350 & 64 & 38 & 47 & 38 & 26 & 563 \\
\hline $\begin{array}{l}\text { Do we really know that the WTO } \\
\text { increases trade? }\end{array}$ & 2004 & 380 & 27 & 27 & 17 & 29 & 13 & 493 \\
\hline An empirical investigation & 2002 & 233 & 20 & 17 & 27 & 19 & 18 & 334 \\
\hline $\begin{array}{l}\text { One money, one market: The } \\
\text { effect of common currencies on } \\
\text { trade }\end{array}$ & 2000 & 246 & 9 & 17 & 22 & 20 & 10 & 324 \\
\hline The Gravity Model & 2011 & 88 & 33 & 35 & 56 & 45 & 30 & 287 \\
\hline $\begin{array}{l}\text { Revisiting the effects of regional } \\
\text { trade agreements on trade flows } \\
\text { with proper specification of the } \\
\text { gravity model }\end{array}$ & 2006 & 151 & 18 & 22 & 22 & 27 & 6 & 246 \\
\hline $\begin{array}{l}\text { Controlling for heterogeneity in } \\
\text { gravity models of trade and } \\
\text { integration }\end{array}$ & 2005 & 139 & 13 & 9 & 12 & 24 & 15 & 212 \\
\hline $\begin{array}{l}\text { On the Specification of the } \\
\text { Gravity Model of Trade: Zeros, }\end{array}$ & & & & & & & & \\
\hline $\begin{array}{l}\text { Excess Zeros and Zero-inflated } \\
\text { Estimation }\end{array}$ & 2009 & 86 & 30 & 17 & 31 & 28 & 14 & 206 \\
\hline $\begin{array}{l}\text { An econometric view on the } \\
\text { estimation of gravity models and } \\
\text { the calculation of trade potentials }\end{array}$ & 2002 & 124 & 18 & 8 & 6 & 13 & 9 & 178 \\
\hline $\begin{array}{l}\text { The impact of mega-sport events } \\
\text { on tourist arrivals }\end{array}$ & 2011 & 40 & 22 & 33 & 20 & 41 & 17 & 173 \\
\hline
\end{tabular}

When the articles with highest citations in the Scopus database are scrutinised, the publication date of the article is demonstrated as 'P.Year' in Table 5 and Table 6 and citations belonging to pre2016 are demonstrated as ' $<2016$ '. When the related number of publications are scrutinised, it is possible to state that the citations to the publications display a similarity each year and that with the increase in the publications about the subject of this model in international commerce, similar increases are expected.

\subsection{Bibliographic Coupling}

Bibliometric coupling, which is very frequently used in the bibliometric analysis studies originates from the idea that the publications which site the similar publications have related research points and serve the same cause (Jarneving, 2007). The main reason of using the method of bibliographic coupling instead of co-citation analysis is the assumption that two publications can be related to each other although they do not give references to each other and that authors do not have the opportunity of scrutinising all the publications realised in the related field. Thereby, bibliographic coupling demonstrates the similarity which cannot be understood via the citation link between two related studies instead of finding direct links (Zupic \& Cater, 2015). The results of the bibliographic match acquired via the VOSviewer is demonstrated in Figure 4 and Figure 5. Publications with same research points are given in the same colour group. Arcuated links between the publications demonstrate the citation relations between the publications. In the bibliographic 
match, it is seen that the groups get closer to each other along with the increase in this link. In this scope, for example, it can be observed that (Rose, 2004), (Rose, 2005), (Nitsch \& Schumacher 2004) and (Morrow et al., 1998) publications match each other bibliographically and they have the same research focus.

According the bibliographic coupling realised for the Scopus database, it was depicted that there were 21 publications between 738 publications with a citation number of 100 and above, and that 20 of these are related to each other. 4 cluster, 115 links, and 237 total link strength were revealed. Among these publications, the publication with the highest total link strength is (Aviat \& Coeurdacier, 2007) with 34 total link strength and 16 links. The related links, clusters and publications are exhibited on Figure 4.

Figure 4: Bibliographic Coupling (VOSviewer) (Scopus)

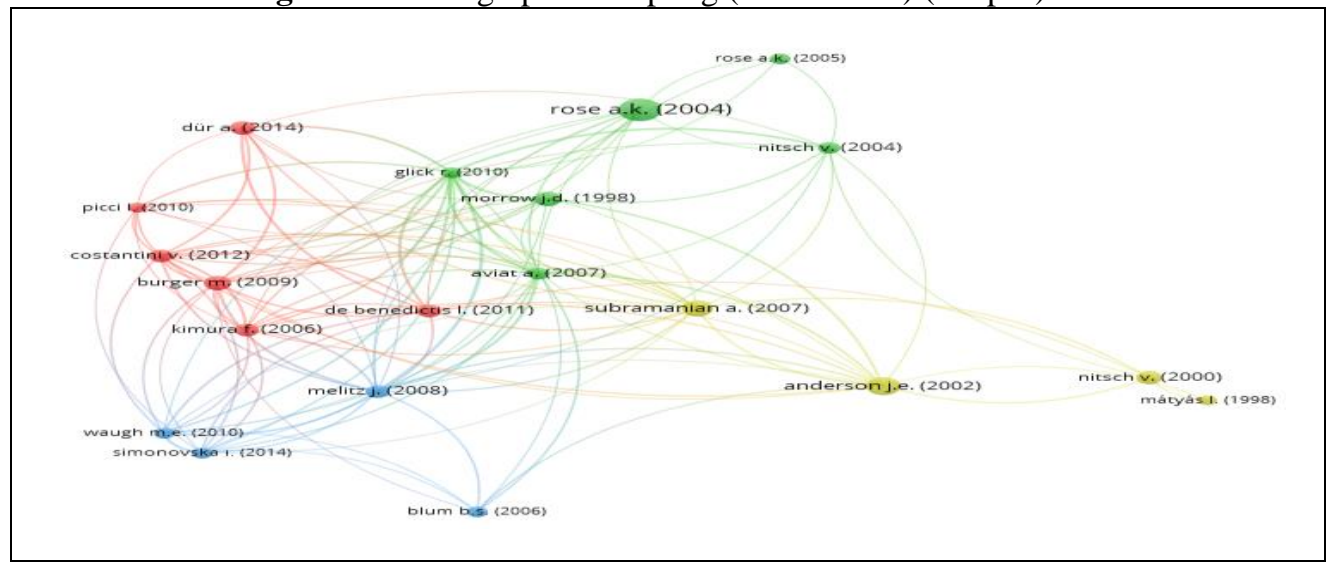

In the analysis executed on Web of science, the 27 publications among 817 with a number of citations above 100 are found to be all related to each other. According to the results, 4 cluster, 207 links and 555 total link strengths have been found out. Among these publications, the publication with the highest total link strength is (Anderson, 2011) with 92 link strength. 
Figure 5: Bibliographic Coupling (VOSviewer) (WoS)

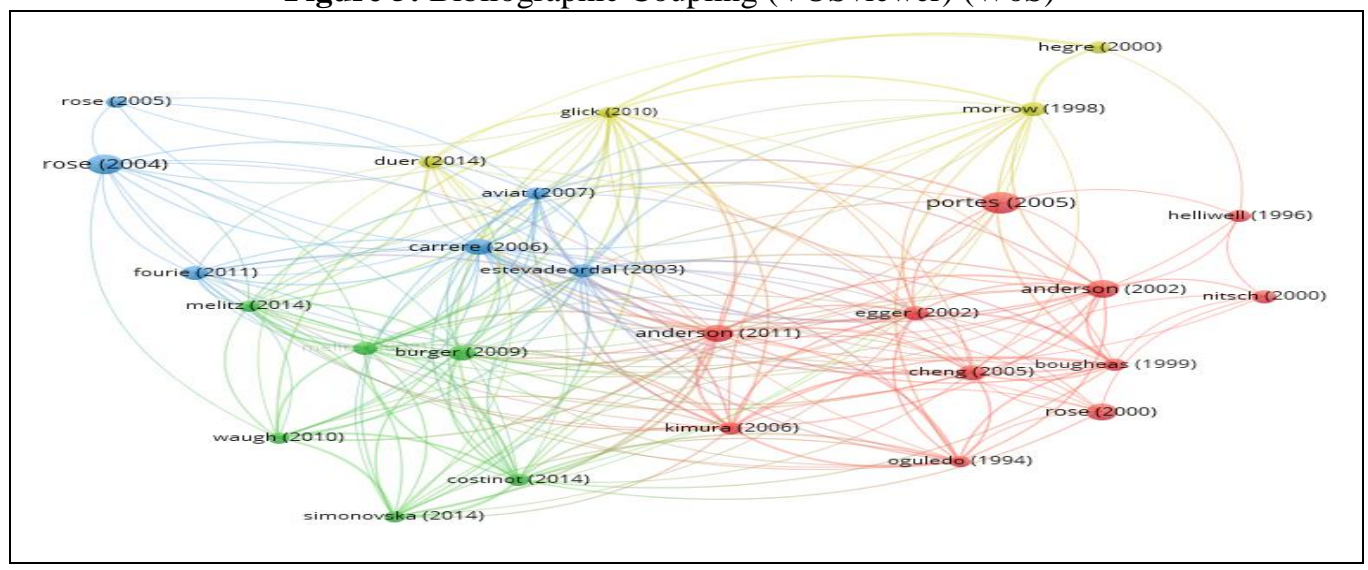

\subsection{The Most Frequently Used Words On The Scopus and Web of Science Database}

In this part of the study the most frequently used words used in the Gravity Model publications that are indexed in the Scopus and Web of Science data index are demonstrated. By omitting the key words, author names, references, titles and summaries, only the most frequently used words have been analysed and they have been tabularised in Table 7 via the R Studio programme.

Table 7: Keyword Analysis on Scopus and Web of Science Database (Most Popular Keywords)

\begin{tabular}{cccc}
\hline \hline Scopus & & \multicolumn{2}{c}{ Web of Science } \\
\hline Words & Occurrences & Words & Occurrences \\
international trade & 348 & international-trade & 415 \\
trade flow & 97 & gravity & 152 \\
export & 86 & gravity equation & 147 \\
gravity model & 81 & equation & 93 \\
bilateral agreement & 60 & impact & 85 \\
modeling & 53 & model & 83 \\
numerical model & 53 & flows & 80 \\
panel data & 45 & specification & 61 \\
china & 43 & agreements & 60 \\
european union & 37 & determinants & 53 \\
europe & 36 & growth & 53 \\
trade relations & 34 & gravity model & 49 \\
trade agreement & 32 & trade & 47 \\
empirical analysis & 31 & countries & 42 \\
commerce & 29 & costs & 41 \\
import & 29 & panel-data & 35 \\
trade policy & 28 & models & 34 \\
developing world & 24 & exports & 32 \\
trade performance & 24 & foreign direct-investment & 31 \\
eurasia & 23 & market & 31 \\
\hline \hline
\end{tabular}

As it can be deduced from Table 7, the most frequently encountered term is "international trade" (348 in Scopus, 415 in Web of Science) since the subject of research is "gravity model and 
international trade". Along with the "international trade" the concepts most frequently used in the Scopus data base are "trade flow" (97), "export" (86), "gravity model" (81), and "bilateral agreement (60). On the WoS data base, these are "gravity" (152), "gravity equation" (147), equation (93) and "impact" (85).

\section{CONCLUSION}

In this research, of the studies published in Scopus and Web of Science database on Gravity Model between 1980-2020 have been limited with those related to the international trade and it was made sure that the term "gravity model" is present in the titles, summaries or key words of these studies. The results have been evaluated under the titles of the development of the research, the most productive and most cited authors, journals with the highest number of publications, the most productive countries, distribution of the most cited publications per year, collaborative studies of countries, bibliographic match and word analysis.

Although studies in the fields of Physics, Astronomy and Engineering are the leading ones, the subject of the gravity equation became a frequently studied subject in the field of foreign trade too. The fact that there were only 1 publication in 1980 and only 1 more in 1984 in two different databases and there have been 40 and 49 publications realised in these data bases solely in the first half of 2020 is demonstrative of this reality. As the publication numbers increase, the citation numbers that the authors receive from each other increase too. The United States of America, Peoples Republic of China and Germany are the countries which have the highest number of publications in this field and the journals with the highest number of publications are "World Economy", "Journal of International Economics" and "Review Of International Economics". The findings of the paper indicate that researches about the gravity model have been significant in the related area. With the help of this study, readers could have a glimpse at the developmental phases of the area of research, they can acquire significant information concerning the subjects such as defining the most productive authors, the most productive journals; and they can learn about the productivity and academic collaboration of analysis of the countries' most influential publications as well as the most frequently used words on Scopus and Web of Science databases.

The article is among the first bibliometric analysis studies in the field of international trade on the subject of gravity executed with three different programmes such as Vosviewer, Gephi and $\mathrm{R}$ Studio. The limitation of the study is the fact that data is only gathered from Scopus and WoS and it is examined using only Gephi, Vosviewer and R Studio programmes. For the following studies, it can be suggested to make the bibliometric analysis with the help of different programmes on various databases and additional studies can be executed originating from this one which compares the results of this study with the results attained on other databases. 


\section{REFERENCES}

Anderson, J. E. (2011). The gravity model. Annual Review of Economics, 3(1), 133-160.

Anderson, J. E., \& Marcouiller, D. (2002). Insecurity and the pattern of trade: An empirical investigation. Review of Economics and Statistics, 84(2), 342-352.

Aviat, A., \& Coeurdacier, N. (2007). The geography of trade in goods and asset holdings. Journal of International Economics, 71(1), 22-51.

Beine, M., Bertoli, S., \& Moraga, F. J. H. (2016). A practitioners' guide to gravity models of international migration. The World Economy, 39(4), 496-512.

Bergstrand, J. H. (1985). The gravity equation in international trade: Some microeconomic foundations and empirical evidence. The Review of Economics and Statistics, 67(3), 474481.

Bergstrand, J. H. (1989). The generalized gravity equation, monopolistic competition and the factor-proportions theory in international trade. The Review of Economics and Statistics, 71(1989), 143-153.

Bikker, J. A. (1987). An international trade flow model with substitution: An extension of the gravity model. Kyklos International Review for Social Sciences, 40(3), 315-337.

Burger, M., Van Oort, F., \& Linders, G. J. (2009). On the specification of the gravity model of trade: zeros, excess zeros and zero-inflated estimation. Spatial Economic Analysis, 4(2), 167-190.

Carrere, C. (2006). Revisiting the effects of regional trade agreements on trade flows with proper specification of the gravity model. European Economic Review, 50(2), 223-247.

Caya, R., \& Neto, J. J. (2018). A bibliometric review about adaptivity. Procedia Computer Science, $130,1114-1119$.

Chaney, T. (2013). The gravity equation in international trade: An explanation. Journal of Political Economy, 126(1), 150-177.

Cheng, I-H. \& Wall, H. J. (2005). Controlling for heterogeneity in gravity models of trade and integration. Federal Reserve Bank of St. Louis Review, 87(1), 49-63.

Costantini, V. \& Mazzanti, M. (2012). On the green and innovative side of trade competitiveness? the impact of environmental policies and innovation on EU exports. Research Policy, 4l(1), 132-153.

De Benedictis, L., \& Tajoli, L. (2011). The world trade network. The World Economy, 34(8), 14171454.

Dür, A., Baccini, L., \& Elsig, M. (2014). The design of international trade agreements: introducing a new dataset. The Review of International Organizations, 9(3), 353-375.

Egger, P. (2002). An econometric view on the estimation of gravity models and the calculation of trade potentials. World Economy, 25(2), 297-312.

Ekanayake, E. M., Mukherjee, A., \& Veeramacheneni, B. (2010). Trade blocks and the gravity model: A study of economic integration among Asian Developing Countries. Journal of Economic Integration, 25(4), 627-643.

Fourie, J., \& Santana-Gallego, M. (2011). The impact of mega-sport events on tourist arrivals. Tourism Management, 32(6), 1364-1370.

Frankel, J. A. (1997). Regional Trading Blocs in the World Trading System. Washington D.C.: Institute for International Economics.

Gencer, A. H. (2012, October 11-13). Gravity modelling of Turkey's international trade under globalization. Paper presented at the International Conference on Eurasian Economies, (pp. 31-34), Almaty, Kazakhstan. 
Gopinath, M., \& Echeverria, R. (2004). Does economic development impact the foreign direct investment-trade relationship? A gravity-model approach. American Journal of Agricultural Economics, 86(3), 782-787.

Irshad, M. S., Xin, Q., Shahriar, S., \& Arshad, H. (2017). A panel data analysis of China's trade pattern with OPEC members: Gravity model approach. Asian Economic and Financial Review, 8(1), 103-116.

Jarneving, B. (2007). Bibliographic coupling and its application to research-front and other core documents. Journal of Informetrics, 1(4), 287-307.

Kaluza, P., Kölzsch, A., Gastner, M. T., \& Blasius, B. (2010). The complex network of global cargo ship movements. Journal of the Royal Society Interface, 7(48), 1093-1103.

Karagöz, K., \& Karagöz, M. (2009). Determining factors of trade flows in the Black Sea economic cooperation BSEC Region a panel gravity model. Akademik Araştırmalar ve Çalışmalar Dergisi, 1(1), 63-75.

Karemera, D., Smith, W. I., Ojah, K., \& Cole, J. A. (1999). A gravity model analysis of the benefits of economic integration in the Pacific Rim. Journal of Economic Integration, 14(3), $347-$ 367.

Kepaptsoglou, K., Karliftis, M.G., \& Tsamboulas, D. (2010). The gravity model specification for modeling international trade flows and free trade agreement effects: A 10-year review of empirical studies. The Open Economics Journal, 2010(3), 1-13.

Kim, K., \& Cohen, J. E. (2010). Determinants of international migration flows to and from industrialized countries: A panel data approach beyond gravity. International Migration Review, 44(4), 8999-932.

Lewer, J. J., \& Berg, H. V. D. (2008). A gravity model of immigration. Economics Letters, 99(1), 164-167.

Linnemann, H. (1966). An Econometric Study Of International Trade Flows. Amsterdam: NorthHolland Publishing Co.

Mele, M., \& Quarto, A. (2017). A gravitational model for estimate the determinants of outward foreign direct investment of China. International Journal of Economics and Financial Issues, 7(1), 1-5.

Merigó, J. M., \& Núñez, A. (2016). Influential journals in health research: A bibliometric study. Globalization and Health, 12(1), 46.

Morrow, J. D., Siverson, R. M., \& Tabares, T. E. (1998). The political determinants of international trade: the major powers, 1907-1990. American Political Science Review, 92(3), 649-661.

Muhuri, P. K., Shukla, A. K., \& Abraham, A. (2019). Industry 4.0: A bibliometric analysis and detailed overview. Engineering Applications of Artificial Intelligence, 78, 218-235.

Nitsch, V. (2000). National borders and international trade: Evidence from the European Union. Canadian Journal of Economics/Revue Canadienne D'économique, 33(4), 1091-1105.

Nitsch, V., \& Schumacher, D. (2004). Terrorism and international trade: An empirical investigation. European Journal of Political Economy, 20(2), 423-433.

Nobre, G. C., \& Tavares, E. (2017). Scientific literature analysis on big data and internet of things applications on circular economy: a bibliometric study. Scientometrics, 111(1), 463-492.

Olczyk, M. (2016). A systematic retrieval of international competitiveness literature: A bibliometric study. Eurasian Economic Review, 6(3), 429-457.

Palmer, A. L., Sese, A., \& Montano, J. J. (2005). Tourism and statistics: bibliometric study 19982002. Annals of Tourism Research, 32(1), 167-178.

Pericoli, F. M., Pierucci, E., \& Ventura, L. (2014). A note on gravity models and international investment patterns. Applied Financial Economics, 24(21), 1393-1400. 
Portes, R., \& Rey, H. (2005). The determinants of cross-border equity flows. Journal of International Economics, 65(2), 269-296.

Rose, A. K. (2000). One money, one market: The effect of common currencies on trade. Economic Policy, 15(30), 08-45.

Rose, A. K. (2004). Do we really know that the WTO increases trade? American Economic Review, 94(1), 98-114.

Rose, A. K. (2005). One reason countries pay their debts: Renegotiation and international trade. Journal of Development Economics, 77(1), 189-206.

Solmaz, A. R., \& Koç, S. (2019). International migration flows in Turkey: A gravity model analysis. Journal of Life Economics, 6(4), 401-412.

Subasat, T., \& Bellos, S. (2013). Governance and foreign direct investment in Latin America: a panel gravity model approach. Latin American Journal of Economics, 50(1), 107-131.

Subramanian, A., \& Wei, S. J. (2007). The WTO promotes trade, strongly but unevenly. Journal of International Economics, 72(1), 151-175.

Tinbergen, J. (1962). Shaping The World Economy. New York: Twentieth Century Fund.

Yeung, A. W. K., Goto, T. K., \& Leung, W. K. (2017). The changing landscape of neuroscience research, 2006-2015: A bibliometric study. Frontiers In Neuroscience, 11(120), 1-10.

Zupic, I., \& Cater, T. (2015). Bibliometric methods in management and organization. Organizational Research Methods, 18(3), 429-472. 